\title{
Utilization of Vegetable Waste Juice by Purple Non-Sulfur Bacterium (Afifella marina Strain ME) for Biomass Production
}

\author{
Sujjat Al Azad*, Wong Hao Jie, Mohammad Tamrin Bin Mohamad Lal \\ Borneo Marine Research Institute, University Malaysia Sabah, Jalan UMS, Kota Kinabalu, Sabah, Malaysia \\ Email: *sujjat@ums.edu.my
}

How to cite this paper: Al Azad, S., Jie, W.H. and Lal, M.T.B.M. (2018) Utilization of Vegetable Waste Juice by Purple Non-Sulfur Bacterium (Afifella marina Strain ME) for Biomass Production. Journal of Geoscience and Environment Protection, 6, 210-219.

https://doi.org/10.4236/gep.2018.65017

Received: April 2, 2018

Accepted: May 22, 2018

Published: May 25, 2018

Copyright $\odot 2018$ by authors and Scientific Research Publishing Inc. This work is licensed under the Creative Commons Attribution International License (CC BY 4.0).

http://creativecommons.org/licenses/by/4.0/

c. (i) Open Access

\begin{abstract}
This experiment was conducted to determine the possibility of utilization of vegetable waste juice in the production of purple non-sulfur bacterium Afifella marina biomass. Bacterium was cultured in four diluted such as, $10 \%, 20 \%$, $30 \%$ and $40 \%(\mathrm{v} / \mathrm{v})$ vegetable waste juices. In addition synthetic 112 media were used as control to compare the growth characteristics of Afifella marine. The bacterium Afifella marina grew well in $10 \%$ diluted vegetable waste juice in anaerobic light condition with the highest production of $5.02 \mathrm{~g} / \mathrm{l}$ dry cell weight in fifth day of culture, whereas the highest total carotenoid production of $0.87 \mathrm{mg} / \mathrm{g}$ dry cell weight was recorded in third day of culture. The highest dry cell weight productions recorded in $10 \%$ of VWJ was significantly higher compared to four other treatments $(F=14.63 ; \mathrm{p}=0.00)$. However, the total carotenoid production of bacteria in $10 \% \mathrm{VWJ}$ showed no significant difference compared to the carotenoid production in 112 synthetic media, but was significantly higher compared to three other treatments $(\mathrm{P}=0.00)$. The bacterium, Afifella marina has the ability to use vegetable waste juice at certain level for the production of bacterial biomass.
\end{abstract}

\section{Keywords}

Afifella marine, Vegetable Waste Juice, Dry Cell Weight and Carotenoid Production

\section{Introduction}

Vegetable growing area in Sabah, Malaysia consists of around 3000 ha and most of the vegetables are produces in high land of Kundasang-Ranau area. Vegetable are prone to spoilage due to their nature and high water composition $(75 \%$ - 
90\%). Spoilage occurs during harvesting, handling, transportation, storage, marketing and processing that resulted waste. These vegetable wastes are usually discarded and dumped in surrounding areas [1]. Nutritional compositions of vegetable waste are dry matter (11.9\%), crude protein (20\%), crude lipids (1.5\%), crude fiber (13.4\%), ash (7.9\%) and nitrogen free extract (65.5\%) [2]. Leafy vegetable waste can be converted to value added product. Considerable attention has been given on recovery, recycling and to convert organic waste into products, such as bio-fuels, multifunctional food ingredients, nutrients, food flavors, fodder feed and operational supply like bio-adsorbents for waste water treatment using various techniques [3]. The waste also contains, starch, cellulose, soluble sugar and organic acids which are utilized by microbes producing biomass of high protein content. The vegetable waste contains high calorific value and nutritive substrate to microbes [4] for the production of single-cell protein [5]. The organic matter from vegetable waste can be easily extracted for the use of single-cell protein cultivation after treatment. Moisture of $41 \%$ and $58 \%$ of organic in vegetable waste can be used as culture medium of algae and production of yeast biomass [6] [7]. Solid state fermentation of vegetable waste using yeast is proven to increase the nutritive composition of crude protein with the value as high as $38 \%$ and $36 \%$ of crude lipid using yeast, Aspergillus niger [8]. On the other hand a $44 \%$ of crude protein increased was obtained by using Chinese cabbage as substrate for the growth of yeast, Kluyveromyces marxianus [7]. Purple non-sulfur bacteria (PNSB) Rhodopseudomonas palustris and Rhodovulum sulfidophilum are potential species in the utilization of food waste, effectively in the utilization of organic matter [9] [10]. PNSB is well known for their ability in transforming organic product for the sources of nutrients. Growth characteristic of PNSB Afifella marina strain ME (KC205142), as well as production of exopolymeric substances like enzymes and nucleic acid has been documented [11]. On the other hand, no studies so far have been conducted with the utilization of waste vegetable juice as substrate for the production of Afifella marina biomass. This study was to determine the possibility of using PNSB, Afifella marine ME (KC205142) for the production of bacterium biomass using various concentration of vegetable juice as substrate.

\section{Materials and Methods}

\subsection{Preparation of Waste Vegetable Juice}

Leafy vegetable waste (LVW) was collected from whole sale vegetable market at Kota Kinabalu, Sabah, Malaysia. The leafy vegetable waste was washed with tap water in Borneo Marine Research Institute (BMRI) Biotechnology laboratory, chopped into smaller pieces and homogenized. The homogenized vegetable waste was filtered through cheese cloth. The separated vegetable waste juice was then be centrifuged at $4000 \mathrm{rpm}$ for 30 minutes. Only supernatant was (PVJ) collected as substrate to be used in experiments. The salinity was adjusted at 29 ppt and $\mathrm{pH}$ at 7 , as bacterium favored with this condition. 


\subsection{Preparation of Inoculums}

Purple non-sulfur bacterium, Afifella marina ME (KC205142) was used in experiments. The strain was taken from BMRI culture collection. The bacterium was cultured in 112 synthetic media for inoculums preparation. The composition of 112 synthetic media was yeast extract $(10 \mathrm{~g})$, di-potassium hydrogen phosphate $(1 \mathrm{~g})$ and magnesium sulfate $(0.5 \mathrm{~g})$. The ingredients of media were mixed well in one liter distilled water and $29 \mathrm{ml}$ was dispensed into several $30 \mathrm{ml}$ universal bottles. The bottles were autoclaved at $121^{\circ} \mathrm{C}$ for 15 minutes for inoculums preparation. One milliliter $(\mathrm{ml})$ of liquid cultured Afifella marina culture was aseptically drawn from BMRI culture stock bottle and poured into universal bottles containing $29 \mathrm{ml}$ of previously prepared sterilized 112 media. The bacteria were incubated anaerobically under 2500 lux of light intensity, at a temperature of $30^{\circ} \mathrm{C} \pm 2^{\circ} \mathrm{C}$. A $48 \mathrm{~h}$ culture was used as inoculums in experimental study.

\subsection{Growth Characteristics of Afifella marina in Pure Vegetable Juice (PVJ)}

Previously prepared vegetable waste juice was used as substrate for the growth of Afifella marina. Three different types of media used as substrate. First, a volume of $29 \mathrm{ml}$ pure vegetable juice, (PVJ) was dispensed into universal bottles. While for second treatment $(\mathrm{PVJ}+\mathrm{E})$, the PVJ was added $5 \%$ of yeast extract. As for control, $29 \mathrm{ml}$ synthetic media 112 media was used. All the bottles were autoclaved at $121^{\circ} \mathrm{C}$ for 15 minutes. After cooling, each bottle was inoculated with $1 \mathrm{ml}$ of 48-h inoculums. Finally, all the inoculated bottles were incubated anaerobically under illumination of 2500 lux of light intensity, at a temperature of $30^{\circ} \mathrm{C} \pm 2^{\circ} \mathrm{C}$ for 6 days.

\subsection{The Effects of Diluted Vegetable Waste Juice (VWJ) on the Growth Characteristics of Afifella marina}

Previously prepared vegetable waste juice (VWJ) was diluted into 10\%, 20\%, $30 \%$ and $40 \% \mathrm{VWJ}(\mathrm{v} / \mathrm{v})$ using 112 synthetic media. $29 \mathrm{ml}$ of diluted vegetable waste was dispensed into universal bottles and autoclaved at $112^{\circ} \mathrm{C}$ for $15 \mathrm{mi}$ nutes. Each bottle was inoculated with $1 \mathrm{ml}$ of 48 -h inoculums of Afifella marina after cooling. All the bottles incubated anaerobically with light and temperature as mentioned before.

\subsection{Analytical Parameters}

The growth characteristics in term of dry cell weight $(\mathrm{mg} / \mathrm{l})$ and the production of total carotenoids ( $\mathrm{mg} / \mathrm{g}$ dry cell weight) were monitored everyday from both experiments. The maximum growth of the bacterium $\left(\mathrm{X}_{\max }\right)$ was determined everyday by using dry cell weight $(\mathrm{g} / \mathrm{L})$ [12]. In brief, to determine the dry cell weight $10 \mathrm{ml}$ of culture was spin down by centrifugation at $5000 \mathrm{rpm}$ for $20 \mathrm{mi}-$ nutes. The packed cell mass was re-suspended again distilled water and centrifuged, the process repeated two times. Finally packed biomass was dried in oven 
at $105^{\circ} \mathrm{C}$ for 24 hours [12]. Total carotenoids in bacterial cells were determined by acetone-methanol extraction. In $10 \mathrm{ml}$ plastic tube $2.5 \mathrm{ml}$ of culture was taken diluted with $2.5 \mathrm{ml}$ of distilled water. The well mixed mixture sample was centrifuged at $5000 \mathrm{rpm}$ for 20 minutes and the supernatant was discarded. The packed suspended cell was re-suspended in $0.1 \mathrm{ml}$ of distilled water added with $4.9 \mathrm{ml}$ of acetone-methanol $(7: 2 \mathrm{v} / \mathrm{v})$. The mixture was homogenized using Vortex and covered with aluminum foil to protect from light and stored at $5^{\circ} \mathrm{C}$ for 30 minutes. The extracted pigment was centrifuged at $5000 \mathrm{rpm}$ at 20 minutes and the supernatant absorbance was measured at $480 \mathrm{~nm}$ with spectrophotometer used acetone methanol as the blank [13]. The specific growth rate ( $\mu_{\max }$ per $\left.h\right)$ was also determined [14].

\subsection{Statistical Analysis}

One-way ANOVA was used to compare the significant differences in mean production of dry cell weight as well as total carotenoid recorded among the treatments of vegetable juice (VJ) used for the culturing of Afifella marina at p < 0.05 significant levels.

\section{Results}

\subsection{Growth Characteristics of Afifella marina in Pure Vegetable Juice (PVJ)}

The dry cell weight of Afifella marina cultured in both pure vegetable juice (PVJ) and the mixture of pure vegetable juice with yeast extract $(\mathrm{PVJ}+\mathrm{E})$ remained low with the production of bacterium biomass of 2.05 and $1.74 \mathrm{~g} / \mathrm{l}$ respectively during the culturing period. The highest growth of $3.74 \mathrm{mg} / \mathrm{l}$ of Afifella marina was observed in synthetic media at $5^{\text {th }}$ day of culture (Table 1 ). The mean dry cell weight production recorded in the 112 media was significantly higher compare to both values recorded in PVJ and PVJ $+\mathrm{E}(\mathrm{p}=0.00)$. However, there was no significant difference between the mean value recorded in PVJ and PVJ $+\mathrm{E}$

Table 1. Growth characteristics of Afifella marine ME (KC205142) in vegetable juice and synthetic media after five days of culture (mean of triplicate \pm sd.) under anaerobic light condition at temperature of $30^{\circ} \mathrm{C} \pm 1{ }^{\circ} \mathrm{C}$.

\begin{tabular}{ccccc}
\hline Treatments & $\begin{array}{c}\mathrm{X}_{\max } \\
(\mathrm{g} / \mathrm{l})\end{array}$ & $\begin{array}{c}\mathrm{X}_{\max } \\
(\mathrm{per} \mathrm{h})\end{array}$ & $\begin{array}{c}\mathrm{Y}_{\mathrm{x} / \mathrm{s}} \\
(\mathrm{g} \text { cell/g substrate })\end{array}$ & $\begin{array}{c}\text { Total Carotenoids } \\
(\mathrm{mg} / \mathrm{g} \text { dry cell weight })\end{array}$ \\
\hline $\begin{array}{c}\text { Pure vegetable Juice } \\
\text { (PVJ) }\end{array}$ & $\begin{array}{c}2.05^{\mathrm{a}} \pm 0.10 \\
(\text { day } 2)\end{array}$ & $0.009 \pm 0.001$ & $0.11^{\mathrm{a}} \pm 0.01$ & $0.56^{\mathrm{a}} \pm 0.01$ (day 2) \\
$\begin{array}{c}\text { Pure vegetable Juice + } \\
\text { Yeast extract } \\
\text { (PVJ + E) }\end{array}$ & $\begin{array}{c}1.74^{\mathrm{a}} \pm 0.20 \\
\text { (day 2 }\end{array}$ & $0.007 \pm 0.001$ & $0.07^{\mathrm{a}} \pm 0.01$ & $0.35^{\mathrm{a}} \pm 0.03$ (day 3) \\
$\begin{array}{c}\text { Synthetic 112 media } \\
\text { (Control) }\end{array}$ & $\begin{array}{c}3.74^{\mathrm{b}} \pm 0.20 \\
\text { (day 5) }\end{array}$ & $0.29 \pm 0.02$ & $0.27^{\mathrm{b}} \pm 0.15$ & $0.76^{\mathrm{b}} \pm 0.13$ (day 4) \\
\hline
\end{tabular}

$\mathrm{X}_{\max }=$ maximum dry cell weight $(\mathrm{g} / \mathrm{l}) ; \mu_{\max }=$ specific growth rate per $\mathrm{h}$. and $\mathrm{Y} \mathrm{x} / \mathrm{y}=$ cell yield $(\mathrm{g}$ cell/g of substrate). Same superscript values indicate no significance differences. 
$(\mathrm{p}=0.339)$. The highest total carotenoid production recorded in 112 media was $0.76 \mathrm{mg} / \mathrm{g}$ on day 4 , whereas the highest values recorded in PVJ and PVJ + E were $0.13 \mathrm{mg} / \mathrm{g}$ dry cell weight on day 0 and $0.12 \mathrm{mg} / \mathrm{g}$ dry cell weight in day 5 respectively.

The mean value of total carotenoid recorded on 112 media was significantly higher than the mean values observed from the PVJ and PVJ $+\mathrm{E}(\mathrm{p}=0.00)$. However, there is no significant difference between values of total carotenoid production recorded in PVJ and PVJ + E $(\mathrm{p}=0.728)($ Table 1).

\subsection{The Effects of Diluted Vegetable Waste Juice (VWJ) on the Growth Characteristics of Afifella marina ME (KC205142)}

The highest dry cell weight of $5.02 \mathrm{~g} / \mathrm{l}$ Afifella marina using 10\% of VWJ was obtained in $5^{\text {th }}$ day of culture. In contrast, the growth of cell was not favorable in $20 \%, 30 \%$ and $40 \%$ of $\mathrm{VWJ}$ with the highest production of only $0.83,0.87,1.10$ $\mathrm{g} / \mathrm{l}$ respectively (Figure 1 ). Statistical analysis showed the mean production of dry cell weight $(\mathrm{g} / \mathrm{l})$ recorded in $10 \%$ of VWJ was significantly higher compare to the mean dry cell weight values of $3.52 \mathrm{~g} / \mathrm{l}$ recorded in 112 media and other diluted VWJ substrates of the experiment $(\mathrm{p}=0.00)$.

Similarly, the total carotenoid production of Afifella marina has been improved in diluted VWJ. The production of carotenoid was favorable using 10\% of VWJ, which reached the highest value of $0.78 \mathrm{mg} / \mathrm{g}$ dry cell weight on day 3 (Figure 2). However, the production of total carotenoid was not favorable in $20 \%, 30 \%$ and $40 \%$ of VWJ and produced only $0.18,0.20$ and $0.14 \mathrm{mg} / \mathrm{g}$ dry cell weight. The mean production of carotenoid in synthetic 112 media with a value of $0.85 \mathrm{mg} / \mathrm{g}$ dry cell weight showed no significant difference compare to the mean value recorded in $10 \% \mathrm{VWJ}(\mathrm{p}=0.956)$. However, there was significant difference between the mean carotenoid production recorded in $10 \% \mathrm{VWJ}$ and the other three treatments, $20 \%, 30 \%$ and $40 \%$ of VWJ $(\mathrm{p}=0.00)$ (Figure 2$)$.

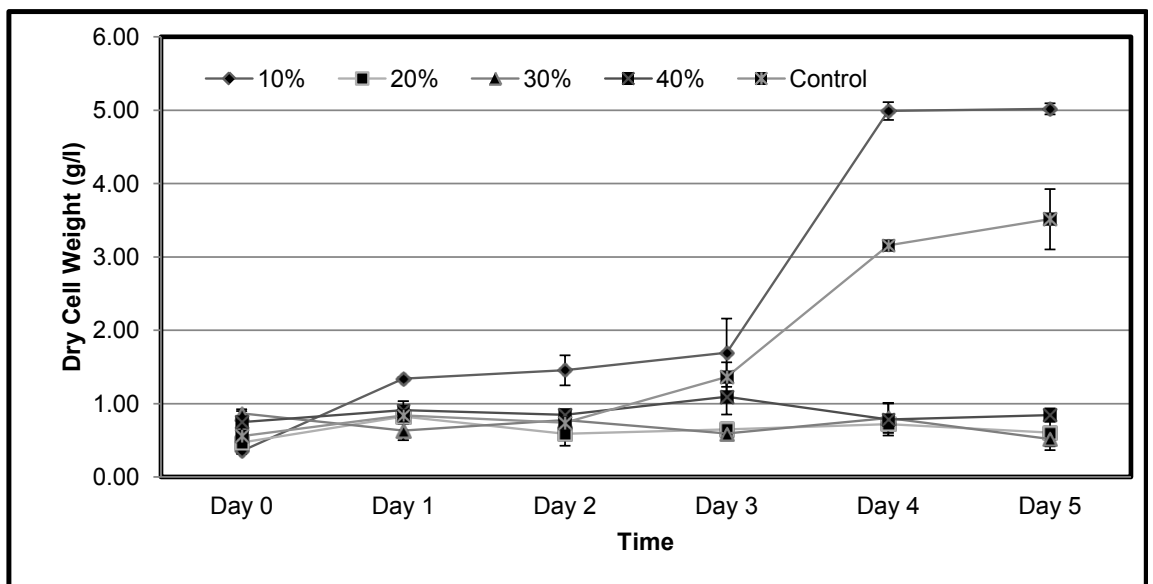

Figure 1. Dry cell weight (g/l) of Afifella marina ME (KC205142) in various concentration of waste vegetable juice at a temperature of $30^{\circ} \mathrm{C} \pm 1{ }^{\circ} \mathrm{C}$ in anaerobic condition under 2500 lux intensity. 


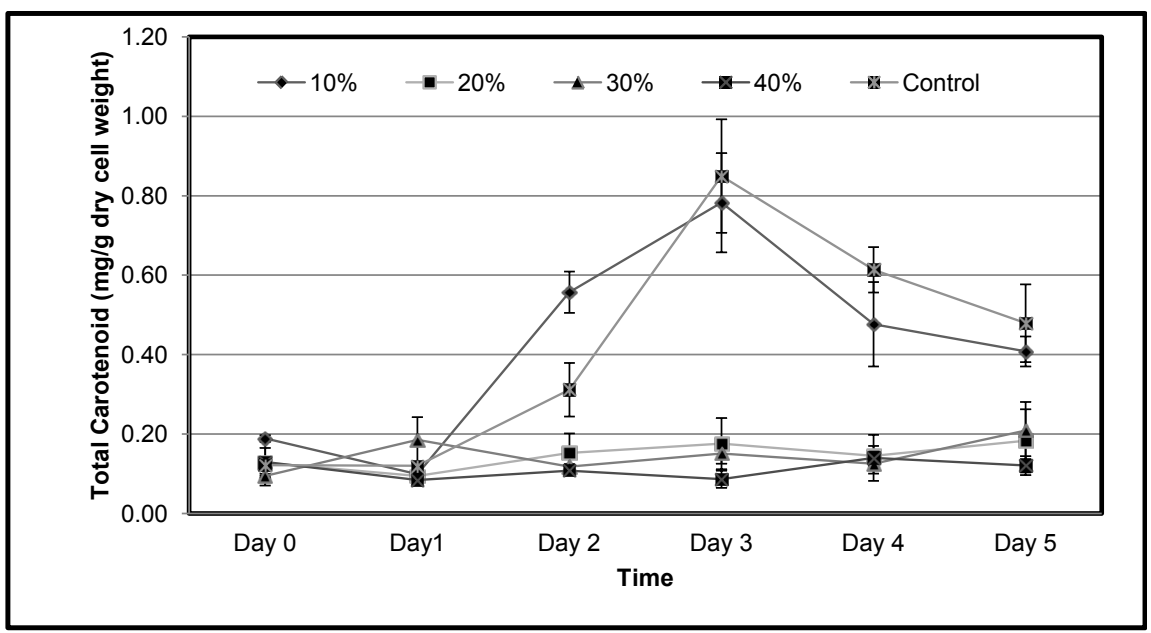

Figure 2. Production of total carotenoids ( $\mathrm{mg} / \mathrm{g}$ dry cell weight) in Afifella marina in various concentration of waste vegetable juice at a temperature of $30^{\circ} \mathrm{C} \pm 1{ }^{\circ} \mathrm{C}$ in anaerobic condition under 2500 lux intensity.

\section{Discussion}

\subsection{Growth Characteristics of Afifella marina in Pure Vegetable Juice (PVJ)}

The growth of Afifella marina was observed in the pure vegetable juice under anaerobic culture condition ( 2500 lux light intensity at $30^{\circ} \mathrm{C} \pm 2^{\circ} \mathrm{C}$ temperature). The current study showed that pure vegetable juice used as substrate was unfavorable to support the growth as well as production of total carotenoids in Afifella marina. The dry cell weight of Afifella marina obtained in PVJ $(2.05 \mathrm{~g} / \mathrm{l})$ and PVJ + E (1.74 g/l) was relatively low compare to dry cell weight of $3.74 \mathrm{~g} / \mathrm{l}$ in synthetic 112.PNSB is well known for their ability in transforming organic product for its own sources of nutrients. The range of dry cell weight (3.77 to $4.34 \mathrm{~g} / \mathrm{l}$ ) and total carotenoid ( 0.71 to $0.78 \mathrm{mg} / \mathrm{g}$ dry cell weight) from 72 and 48 $\mathrm{h}$ cultures was observed [15]. The highest dry weight of biomass of $0.39 \mathrm{~g} / \mathrm{l}$ achieved in the 216-h culture was comparatively lower than this study, but the specific growth rate of 0.2960 per hour was achieved higher in their study compare to this study (in 0.009 per hour) [16]. Although the specific growth rate of 0.29 was obtained in this study while cultured in synthetic 112 media. Mean bacterial biomass was significantly higher in treated waste water of than synthetic media, confirming the adaptability of $R$. gelatinosus to poultry slaughterhouse wastewater and the suitability of waste and cultivation conditions for the bacterial growth [16]. The unfavorable growing condition of Afifella marina in PVJ might be due to the presence of antibacterial activity in cabbage, although antibacterial activity of PVJ was not studied in the experiment. Parts of vegetable waste collected for this study contains cabbage. A non-protein sulfur amino acid, S-Methyl-L-cysteine sulfoxide (SMCSO) was reported in cabbage [17]. SMCSO undergoes enzymatically reaction to form methyl methanethiosulfonate $\left(\mathrm{MMTSO}_{2}\right)$, which is growth inhibitor for bacteria [17]. These compounds are more pro- 
nounced against gram-negative bacteria, such as Afifella marina, than against gram-positive types of bacteria. On the other hand the inhibitory activity of cabbage juice related to antibacterial substance can be destroyed by heat treatment. Better growth medium for Lactic acid bacteria was Fresh filter-sterilized cabbage juice [18]. The cell mass production of four types of yeast using cabbage juice as substrate was in the range of 6 to $10 \mathrm{~g} / \mathrm{l}$ [7]. Further the addition of cabbage juice into waste brine stimulated the growth of yeast. The dry cell weight of Pichia guilliermondii was obtained of $1.35 \mathrm{~g} / \mathrm{l}, 1.87 \mathrm{~g} / \mathrm{l}$ and $2.75 \mathrm{~g} / \mathrm{l}$ with the 5\%, $10 \%$ and $20 \%$ of cabbage juice respectively and thus growth was limited by the low carbon content of waste brine [7]. The possibility of insufficient nutrient in PVJ might be the cause of growth inhibition in which it requires to dilute the pure vegetable juice for satisfactory growth of bacteria. PNSB can utilize the wider range of nutrition that allows them to grow on virtually any organic materials and are efficient, dominant mediators for organic and nutrient removal from poultry, red meat, pork, and to a lesser extent, dairy and sugar wastewater [19]. Yeast extract is an important source of nitrogen and thiamine for the synthesis of amino acids and nucleic acids in bacterial cells [20]. Five percent of yeast extract added to the treatment of PVJ $+\mathrm{E}$ was providing higher nutrients available compare to 112 synthetic media (Control), which had only one percent of yeast extract. The growth of Afifella marina using 112 synthetic media contain only one percent of yeast extract had showed a better growth in the production of cellular polymeric substances [13]. The dilution of autoclaved cabbage juice favors the growth of bacteria, Staphylococcus aureus, at less than $40 \%$ of cabbage juice. Hence, the factor of growing inhibition was possibly due to the presence of growth suppressing compounds rather than the insufficient of nutrients [17].

\subsection{The Effects of Diluted Vegetable Waste Juice (VWJ) on the Growth Characteristics of Afifella marina}

Afifella marina grew normally at $10 \%$ diluted VWJ under anaerobic culture condition as dilution of VWJ might be able to reduce the concentration of certain growth inhibitory compounds [17]. The highest dry cell weight of Afifella marina recorded in $10 \%$ of VWJ with the value of $5.02 \mathrm{~g} / \mathrm{l}$ on day 5 was significantly higher than the highest dry cell weight production recorded with the value of $3.52 \mathrm{~g} / \mathrm{l}$ using 112 synthetic media. The maximum bacteria biomass reported in current study was lower to dry cell weight of $4.8 \mathrm{~g} / \mathrm{l}$ Rhodovolum sulfidophilum using sardine processing wastewater as culture substrate [10]. In comparing to other purple non-sulfur bacteria, the dry cell weight observation was relatively similar with the amount of $3.63 \mathrm{~g} / \mathrm{l}$ using Rhodobacter sphaeroides strain Z08 [21]. Thus the growth characteristics of purple non-sulfur bacteria depend on the nutrients of substrate. Experiments conducted by other authors to investigate growth characteristics of phototrophic bacteria on different wastewaters revealed diverse dry cells weights and specific growth rates, according to the organisms and cultivation conditions. The maximal cell concentration of mixed-PSB 
can up to $852.3 \mathrm{mg} / \mathrm{l}$ in anaerobically digested swine wastewater, but in the observation of treatment by unitary strains separately the growth rate of $R$. blasticus was faster than the $R$. capsulatus at the first $72 \mathrm{~h}$, but after that, due to the nutritional stress, the $R$. blasticus population abandoned exponential growth and entered a non-growth state called stationary phase [22]. The organic matter in wastewater provides essential nutrients to the growth of microorganism. However, too high or low concentration of the wastewater affects the osmotic pressure on microbial cells, which disadvantageous at nutrient absorption and bacterial growth and propagation. Thus in diluted wastewater, the biomass was also decreased [22]. The incubation period for the harvesting of Afifella marina for single cell protein production in $10 \% \mathrm{VWJ}$ was shorter compare to the study of [10] using Rhodovolum sulfidophilum in sardine processing waste water. Afifella marine reached stationary phase on day 3 , similar to the study using Rhodovolum sulfidophilum [21] suggested that this strain of bacteria was fast growing and perhaps can be biotechnologically manipulated for large-scale production of single cell protein using waste as substrate [15]. Meanwhile, the total carotenoid production of Afifella marina in $10 \% \mathrm{VWJ}$ did not showed significance difference compare to the using of 112 synthetic media $(\mathrm{p}=0.956)$. Both yielded the maximum carotenoid production on day 3 of 0.78 and $0.85 \mathrm{mg} / \mathrm{g}$ dry cell weight for $10 \% \mathrm{VWJ}$ and 112 media respectively. The maximum total carotenoid observation was relatively similar as compare to other study. The highest production total carotenoid of $0.8 \mathrm{mg} / \mathrm{ml}$ was recorded at 2000 lux light intensity, whereas the total carotenoid of $0.5 \mathrm{mg} / \mathrm{ml}$ and $0.7 \mathrm{mg} / \mathrm{ml}$ were recorded on both 1000 and 3000 lux light intensity respectively [20]. However, the maximum total carotenoid in current study was relatively lower as compared to the study, which yielded the maximum value of $1.2 \mathrm{mg} / \mathrm{g}$ dry cell weight within 24 hours at 2000 lux light intensity using Rhodopseudomonas sp. in waste water treatment [23]. Higher frequency of the light/dark cycle leaded to higher biomass production, which signified a higher photosynthetic efficiency [24]. However the amount of carotenoid produced by purple non-sulfur bacterium directly determines the energy captured bacteria and affects the growth characteristics such bacteria.

\section{Conclusion}

Purple non-sulfur bacteria, Afifella marina, grew well in waste vegetable juice, but at certain level. Although Afifella marina could not be cultured in pure vegetable juice under anaerobic culture condition, but $10 \%$ diluted vegetable waste juice was favorable for the growth of Afifella marina in term of dry cell weight $(\mathrm{mg} / \mathrm{l})$ and production of total carotenoids $(\mathrm{mg} / \mathrm{g}$ dry cell weight). The nutritionally enriched bacterial dry cell biomass can be used as feed additive or diet supplement to culture aquaculture species [10].

\section{Acknowledgements}

This study was supported by the grant of SBK0307.2017 from University Malay- 
sia Sabah, Kota Kinabalu, Sabah, Malaysia and authors also appreciated the support from staff of Borneo Marine Research Institute, University Malaysia Sabah, Kota Kinabalu, Sabah, Malaysia.

\section{References}

[1] Jipanin, J., Rahman, A.A., Jaimi, J.R. and Phua, P.K. (2001) Management of Pesticide Use on Vegetable Production: Role of Department of Agriculture, Sabah. 6 th SITE Research Seminar, Kota Kinabalu, 13-14 September 2001, 21.

[2] Asquer, C., Pistis, A. and Scano, E.A. (2013) Characterization of Fruit and Vegetable Wastes as a Single Substrate for Anaerobic Digestion. Environmental Engineering and Management Journal, 12, 89-92

[3] Laufenberg, G., Kunz, B. and Nystroem, M. (2003) Transformation of Vegetable Waste into Value Added Products: (A) The Upgrading Concept; (B) Practical Implementations. Bioresource Technology, 87, 167-198. https://doi.org/10.1016/S0960-8524(02)00167-0

[4] Prakash, E.V. and Singh, L.P. (2013) Biomethanation of Vegetable and Fruit Waste in Co-Digestion Process. International Journal of Emerging Technology and Advanced Engineering, 3, 493-495.

[5] Stabnikova, O., Wang, J.-Y., Ding, H.B. and Tay, J.-H. (2005) Biotransformation of Vegetable and Fruit Processing Waste into Yeast Biomass Enriched With Selenium. Bioresource Technology, 96, 747-761. https://doi.org/10.1016/j.biortech.2004.06.022

[6] Pleissner, D., Lam, W.C., Sun, Z. and Lin, C.S. (2013) Food Waste as Nutrient Source in Heterotrophic Microalgae Cultivation. Bioresource Technology, 137, 139-146. https://doi.org/10.1016/j.biortech.2013.03.088

[7] Choi, M.H., Ji, G.E., Koh, K.H., Ryu, Y.W., Jo, D.H. and Park, Y.H. (2002) Use of Waste Chinese Cabbage as a Substrate for Yeast Biomass Production. Bioresource Technology, 83, 251-253. https://doi.org/10.1016/S0960-8524(01)00232-2

[8] Rajesh, N., Imelda-Joseph and Paul Raj, R. (2010) Value Addition of Vegetable Wastes by Solid-State Fermentation Using Aspergillus niger for Use in Aqua-Feed Industry. Waste Management, 30, 2223-2227. https://doi.org/10.1016/j.wasman.2009.12.017

[9] Mekjinda, N. and Ritchie, R. (2015). Breakdown of Food Waste by Anaerobic Fermentation and Non-Oxygen Producing Photosynthesis Using a Photosynthetic Bacterium. Waste Management, 35, 199-206. https://doi.org/10.1016/j.wasman.2014.10.018

[10] Azad, S.A., Vikineswary, S. and Chong, V.C. (2003). Rhodovulum sulfidophilum in the Treatment and Utilization of Sardine Processing Wastewater. Letters in Applied Microbiology, 38, 13-18. https://doi.org/10.1046/j.1472-765X.2003.01435.x

[11] Azad, S.A., Tan, K.S. and Ransangan, J. (2013) Effects of Light Intensities and Photoperiods on Growth and Proteolytic Activity in Purple Non-Sulfur Marine Bacterium, Afifella marina Strain ME (KC205142). Advances in Bioscience and Biotechnology, 4, 919-924. https://doi.org/10.4236/abb.2013.410120

[12] Sawada, H., Parr, R.C. and Rogers, P.L. (1977). Photosynthetic Bacteria in Waste Treatment. Journal of Fermentation Technology, 55, 326-336.

[13] Jensen, S.L. and Jensen, A. (1971) Quantitative Determination of Carotenoids in Photosynthetic Tissue. In: Pietro, A.S., Ed., Methods in Enzymology Vol 23, Academic Press, New York, 586-602. 
[14] Sasaki, K. and Nagai, S. (1979) The Optimum pH and Temperature for the Aerobic Growth of Rhodopseudomonas gelatinosa, and Vitamin B12 and Ubiquinone Formation on a Starch Medium. Journal of Fermentation Technology, 57, 383-386.

[15] Tan, K.S., Azad, S.A. and Ransangan, J. (2014) Isolation and Characterization of Purple Non-Sulfur Bacteria, Afifella marina, Producing Large Amount of Carotenoids from Mangrove Microhabitats. Journal of Microbiology and Biotechnology, 24, 1034-1043. https://doi.org/10.4014/jmb.1308.08072

[16] Ponsano, E.H.G., Paulino, C.Z. and Pinto, M.F. (2008) Phototrophic Growth of Rubrivivax gelatinosus in Poultry Slaughterhouse Wastewater. Bioresource Technology, 99, 3836-3842. https://doi.org/10.1016/j.biortech.2007.06.063

[17] Kyung, K., Han, D. and Fleming, H. (1997) Antibacterial Activity of Heated Cabbage Juice, S-methyl-L-cysteine Sulfoxide and Methyl Methanethiosulfonate. Journal of Food Science, 62, 406-409. https://doi.org/10.1111/j.1365-2621.1997.tb04013.x

[18] Yildiz, F. and Westhoff, D. (1981) Associative Growth of Lactic Acid Bacteria in Cabbage Juice. Journal of Food Science, 46, 962-963. https://doi.org/10.1111/j.1365-2621.1981.tb15397.x

[19] Hülsen, T., Hsieh, K., Lu, Y., Tait, S. and Batstone, D.J. (2018) Simultaneous Treatment and Single Cell Protein Production from Agri-Industrial Wastewaters Using Purple Phototrophic Bacteria or Microalgae-A Comparison. Bioresource Technology, 254, 214-223. https://doi.org/10.1016/j.biortech.2018.01.032

[20] Ainon, H., Tan, C. and Vikineswary, S. (2006) Biological Characterization of Rhodomicrobium vannielii Isolated from a Hot Spring at Gadek, Malacca, Malaysia. Malaysian Journal of Microbiology, 138, 663-670.

[21] Wu, P., Zhang, G. and Li, J. (2015) Mg2+ Improves Biomass Production from Soybean Wastewater Using Purple Non-Sulfur Bacteria. Journal of Environmental Sciences, 28, 43-46. https://doi.org/10.1016/j.jes.2014.05.040

[22] Wen, S., Liu, H., He, H., Luo, L., Li, X., Zeng, G., Zhou, Z, Lou, W. and Yang, C. (2016) Treatment of Anaerobically Digested Swine Wastewater by Rhodobacter blasticus and Rhodobacter capsulatus. Bioresource Technology, 222, 33-38. https://doi.org/10.1016/j.biortech.2016.09.102

[23] Zhou, Q., Zhang, P. and Zhang, G. (2014) Biomass and Carotenoid Production in Photosynthetic Bacteria Wastewater Treatment: Effects of Light Intensity. Bioresource Technology, 171, 330-335. https://doi.org/10.1016/j.biortech.2014.08.088

[24] Zhou, Q., Zhang, P., Zhang, G. and Peng, M. (2015) Biomass and Pigments Production in Photosynthetic Bacteria Wastewater Treatment: Effects of Photoperiod. Bioresource Technology, 190, 196-200. https://doi.org/10.1016/j.biortech.2015.04.092 